\title{
Subjectivity and Transcendental Illusions in the Anthropocene
}

\author{
Helena De Preester ${ }^{1}$ \\ Published online: 8 February 2021 \\ (C) The Author(s) 2021
}

\begin{abstract}
This contribution focuses on one member in particular of the anthropocenic triad Earth - technology - humankind, namely the current form of human subjectivity that characterizes humankind in the Anthropocene. Because knowledge, desire and behavior are always embedded in a particular form of subjectivity, it makes sense to look at the current subjective structure that embeds knowledge, desire and behavior. We want to move beyond the common psychological explanations that subjects are unable to correctly assess the consequences of their current technological lifestyle or unable to change their lifestyle because well-intended behavior is modified by factors such as laziness, lack of knowledge, seduction by convenience, etc. Instead, we will argue from a philosophical point of view that transcendental illusions play a central role in a contemporary account of subjectivity. Consumerism is considered as a means of not becoming a subject and framed in a profound ambivalence at the heart of our acting (consuming) against better knowledge. We appeal to collective transcendental conditions of subjectivity in the Anthropocene in terms of illusions without owners - a term borrowed from Robert Pfaller's work on interpassivity. Central in our account is the idea that illusions without owners are the conditions of possibility for the disconnection between knowledge and behavior - the characteristic par excellence of the Anthropocene.
\end{abstract}

Keywords Subjectivity $\cdot$ Anthropocene $\cdot$ Consumerism $\cdot$ Ambivalence $\cdot$ Illusions without owners $\cdot$ Commodification

And then there are people who write despite knowing that it makes no sense.

(Vilém Flusser 2011a, p. 161)

Tout va très bien, Madame la Marquise.

(from a French song by Paul Misraki 1935)

Helena De Preester

helena.depreester@hogent.be

1 School of Arts, University of Applied Sciences and Arts, Ghent \& Department of Philosophy and Moral Sciences, Ghent University, Ghent, Belgium 


\section{Introduction}

This contribution focuses on one member in particular of the anthropocenic triad Earth - technology - humankind, namely the current form of human subjectivity that characterizes humankind in the Anthropocene. Unsurprisingly, the role of human subjectivity as an important factor in the current ecological catastrophe is presented here in terms of humankind's compulsive consumerist behavior. However, we want to move beyond the idea that humankind goes on destructing the Earth because human subjects are unable to correctly assess the consequences of our current technological lifestyle or unable to change this lifestyle because well-intended behavior is modified by factors such as laziness, lack of knowledge, seduction by convenience, etc. Because knowledge, desire and behavior are always embedded in a particular form of subjectivity, it makes sense to look at the current subjective structure that embeds knowledge, desire and behavior. We will argue that transcendental illusions play a central role in a contemporary account of subjectivity.

In the next two sections, we move from the idea that consumerist capitalism destroys subjectivity to the idea that consumption is a means of not becoming a subject, and that a profound ambivalence towards consumerism is at the heart of our acting against better knowledge. In Sect. 2, some well-known ideas about subjectivity and desire in consumerist capitalism and the role of current technology are presented. The idea of consumption as a means of not becoming a subject is elaborated in Sect. 3, and the idea of a profound ambivalence towards consumerism at the heart of our acting against better knowledge in Sect. 4. Based on the results of the previous sections, Sect. 5 discusses the collective transcendental conditions of subjectivity in the Anthropocene in terms of illusions without owners - a term borrowed from Robert Pfaller's work on interpassivity. Central in our account is the idea that illusions without owners are the conditions of possibility for the disconnection between knowledge and behavior - the characteristic par excellence of the Anthropocene. In the sixth and final section, we suggest a different perspective on ecological awareness and the end of illusions without owners.

\section{From the Commodification of Information to the Commodification of Desire}

Present-day consumerist capitalism is largely driven by mass-marketing techniques that increasingly rely on the commodification of information, and that lie at the heart of the 'attention economy' (Williams 2018). McKenzie Wark, in A Hacker Manifesto (2004), identifies the "vectoralist class" as a new leading class now in power. The vectoralist class is constituted by the possession of information and the capacity to transform this information and extract new value from it. The vectoralist class owes its name to its control over the vectors, that is, the pathways and networks over which information flows: “(...) it is the vectoralist class that owns and controls the means of production of information on an industrial scale. Their interests lie in extracting as much margin as possible from information, in commodifying it to the nth degree" (Wark 2004, p. 133). That requires the possession of big data technologies capable of transporting information through time (storage) and space (along a certain vector). The productive classes, in contrast, do not "control the means by which information is extracted from their lives and returned to them in form of the commodity" (Wark 2004, p. 334). The commodification of information happens by 
capturing information flows within the commodity form, with the concomitant transformation of subjects into consumers.

Even worse, what present-day consumers consume, is their own subjectivity. The new leading class "profits from the producing class as consumer of its own subjectivity in commodified form" (Wark 2004, p. 170). According to Wark, subjectivity is only partial under the vectoralist reign, since it is only viewed as a resource by the vector. This is experienced by the subject as a loss or a lack of subjectivity, "which it may seek to fulfil through the very same field of values - the field of the vector - that produces the lack in the first place" (Wark 2004, p. 341). In other words, the subject is caught in a vicious circle of consumption, in which it tries to make up for the loss of subjectivity, caused by consuming, by consuming more.

Bernard Stiegler describes this same phenomenon in terms of a cycle of addiction. The transformation of subjects into consumers leads to herdish behavior and is at odds with the knowledge one has of one's singularity or being-unique. This loss of a relation to one's own singularity provokes a malaise, "a dangerous dissatisfaction with oneself and a profound loss of belief in the future, the paradox being that this malaise and this feeling of loss in fact reinforce the herdish tendency itself, through a retroactive loop constituting a vicious circle" (Stiegler 2011, p. 28). Consumption and the concomitant herdish behavior induce anxiety and this reinforces consumer behavior that tries in vain to be relieved of this anxiety. Caught in a vicious feedback loop that reinforces consumption, consumerist behavior shows a pattern typical of addiction. "Addiction is the effective reality of the dominant industrial model. This addiction is an annihilation of the subject of the addiction by the object of addiction [consumption] (...)" (Stiegler 2011, p. 28).

We are at the heart of the control society, that deliberately turns the population into a consumer market and that trains consumer behavior, "and it is for this reason that it is a matter of desubjectivation, that is, a programmed destruction of the singularity of savoirvivre" (Stiegler 2011, p. 81). The problem of desire becomes central here, because it is in the interest of the vectoralist class that desire is thought of as having an object, and that this object is thought of as commodity (Wark 2004, p. 279). Whatever form desire takes, the image of desire is always rapidly commodified. Objectified desire recruits subjects for the production of objects, and presents these objects as what the subject desires. Subjectivity is enslaved to objects of desire, to commodification.

Liberating the vector would mean that the subject would no longer be desubjectified or disindividuated as consumer, but may become capable again of producing its own ways of existence. Liberating the vector amounts to freeing oneself from a form of subjectivity that is thrust upon the subject in the interest of enslaving that subjectivity to particular objects of desire. A step further in this process of liberation would be to free desire from any commodification whatsoever (Wark 2004, p. 294). However, mass-marketing techniques redirect individuals' desires again and again to commodities, and regulate and control their behavior. Big data technologies in the hands of capitalism means that capitalism reigns over people's desires. Therefore, the consumer is the new proletarian figure, submitted to standardized behavioral models of consumption. The reduction of the citizen (of the psychic and collective individual) to consumer and the reduction of social control to behavioral control are central in this process. Because the libidinal economy (i.e. the economy of desire) is disturbed by current industrial economy, new ways of life are no longer invented (Stiegler 2011).

The computational nature of capitalism tends to eliminate all values not calculable on the market of economic exchange. Consciousness itself, especially its limited resources of attention, has become a commodity, and desire is industrially exploited in an unlimited 
way. "Today (...) libido, desire in the Freudian sense has become the object of calculation with a view towards systematic exploitation (...)" (Stiegler 2011, p. 88). Libidinal energy being exhausted, the psychic and collective individuation is under threat (disindividuation).

Stiegler calls this kind of society that exhausts desire 'irrational', because it demotivates those who constitute the society. It is a loss of savoir-vivre that is at stake, a loss of existence, a loss of being in the world in a singular way. Consumers themselves have become standardized in their behaviors "by the formatting and artificial fabrication of their desires: they lose their savoir-vivre, that is, their possibilities of existence" (Stiegler 2011, p. 105). Stiegler explains how in the end, hyper-industrial capitalism (i.e. including cultural capitalism) leads to a destruction of the motives for producing and consuming. The irrationality of current hyper-industrial capitalism can remain hidden as long as the belief that economic expansion is also social progress remains intact. This belief, however, is no longer tenable. All motives (apart from addictive motives) are worn down, and the result is not only economic, but also political decadence. Motives are substituted by addictions. What is left, instead of the desire to elevate oneself, is the herd that consumes.

The view of the subject as having the desire to elevate oneself, and that opposes itself in order not to fall prey to the base tendencies that are always present in the subject, is of particular interest. The individual is dynamically composed of opposed tendencies, such that one tendency cannot exist without the other. At times, some tendencies can become hegemonic and tend to eliminate the opposing tendencies. That destroys the dynamic relation through which the individual is constituted (Stiegler 2011, p. 38). According to Stiegler (2011), the exploitation by hyperindustrial societies elicits the more base tendencies, which tend to become hegemonic, renunciating life and hindering a belief in the future. Yet the economy of the libido cannot be reduced to the computation of capital. According to Wark, the true battle is not for a particular image of desire, but for the means of production of desire (i.e. the vector itself). "The means of production of desire - the vectors along which can flow an immaterial surplus of information is the first and last point at which the struggle to free subjectivity is to be waged (...). The liberation of the vector is the one absolute prohibition of the vectoral world, and the point at which to challenge it" (Wark 2004, p. 296). Stiegler and Wark assume a desire to elevate oneself (Stiegler) or to be able to produce a desire oneself (Wark), a desire for subjectification or individuation, opposing a loss of future (or history more generally).

\section{Digital Technologies, Desire for Happiness and the End of History}

In Does writing have a future, Vilém Flusser (2011a [1987]) analyzes the effects of the rise of the digital on the older tradition of (alphabetic) writing. Apparently, he shares the oftenheard complaint that whereas print has resulted in a comprehensive, democratizing literacy, a new literate caste has arisen because new computer codes have made us all illiterate again (Flusser 2011a, p. 55). Both the new vectoralist class identified by Wark and Stiegler's new proletarian figure of the consumer took form in the slipstream of the digitalization of writing. ${ }^{1}$ However, the difference between alphabetic and digital writing does not lie in the

\footnotetext{
1 Of course, earlier Hertzian mass media such as radio and television also had a role to play. Interestingly, Flusser (1977) considers television as an inversion of politics: it makes private what was previously public, resulting in depoliticization and loneliness of the crowd. Television is abused as a tool to manipulate lonely and alienated masses.
} 
programming purpose. Flusser states that writing has served the purpose of programming behavior since its invention, and thus always has been instructive and manipulative in purpose - from the Ten Commandments to constitutional laws. Moreover, all instruction seeks machine-like automatic behavior. The difference between (old) alphabetic and (new) digital writing is to be sought in the fact that people no longer need explicit instruction (in terms of 'should') in order to steer their behavior. With the advent of digital programming and the automation of apparatuses, it becomes superfluous to instruct or to manipulate people. According to Flusser, behavior eventually becomes functionalized, depoliticized and valuefree (i.e. not instructed by ideology or values), because there is no 'should' in computer programs.

In more recent terms, the regime of hypernudge (i.e. nudging in the context of big data) with its soft power does not forbid or oblige, nor does it directly manipulate people. It is the digital environment of the individual that is continuously and dynamically adapted, according to the purposes of the choice architect, that is, the one organizing the environment in which people make decisions (Yeung 2017). The result is that without direct instruction, humans tend to behave according to the direction suggested by the nudges. Or in Flusser's terms: "(...) human beings and their society will steer themselves automatically" (Flusser 2011a, p. 57).

However, Flusser was less prescient than these similarities suggest. For Flusser, digital programming opens up the possibility that "people can concentrate on programming apparatuses", instead of being instructed themselves. And, he adds, "could that not be the freedom we have sought since history began?" (Flusser 2011a, p. 58) Freedom arises when human behavior has become 'free', this is, not instructed or manipulated by ideology or values, but purely functional. The goal of history is achieved when all behavior has become functionalized, apolitical and value-free. Such deeply profane behavior is literally meaningless and therefore absurd, but people are now free to give meaning to this meaningless and absurd behavior. The goal of history being achieved implies that "history, and the mode of thought that produces history, is over" (Flusser 2011a, p. 59).

Flusser did not foresee or discuss the intimate interweaving of digital programming and capitalism, which resulted in the unprecedented manipulative power of the current vectoralist class. Whereas Flusser had free individuals in mind (although facing the absurdity of their behavior), he also forwarded the possibility that we would be free to program apparatuses. This did not become true, because it is not the everyday individual that programs, but the new ruling class of vectoralists, which possesses the information and the algorithms used to manipulate an individual's environment and behavior.

Algorithmic governmentality aims to intervene on the environment of individuals and is not accompanied by a focus on individuals. On the contrary, subjects are avoided because supra-individual models of behavior are obtained on the basis of correlations that emerge from processing infra-individual mass data. "Algorithmic governmentality produces no subjectification, it circumvents and avoids reflexive human subjects, feeding on infraindividual data which are meaningless on their own, to build supra-individual models of behaviour or profiles without ever involving the individual, and without ever asking them to themselves describe what they are or what they could become" (Rouvroy and Berns 2013, p. 10). More specifically, individuals are approached on the basis of their profile or their statistical double, not on the basis of their capacity for understanding, will or expression - capacities involved in processes of subjectification. Algorithmic governmentality aims "to prompt individuals to act without forming or formulating a [true, as opposed to commodified] desire" (ibid. p. 13). Ideally, there is no subject anymore between the stimuli in the dynamic environment and the response (consuming, voting, health behavior, ...). 
There is no direct confrontation with a public and discursive norm that is visible or readable (a law, a definition of normality, an average, ...), but the possibilities and impossibilities for reacting are built into the environment itself, exerting soft power. Rouvroy and Berns (2013) explain how this new type of statistical normativity is part of the environment itself and constantly and dynamically shaped and constrained by behavior itself, rendering any act of resistance futile, since it is immediately processed as part of the statistical double.

However, Flusser's apparently uncritical embrace of the digital also turns into a profound critique of this new era. Alphabetic writing is the mode of thought that produces history, because of its inherent linear mode of thinking. Now that all domains are programmable, there is no domain left where alphabetic writing, and thus historical, political, ethical and aesthetical modes of thought can be preserved. Because of the disappearance of alphabetic writing, a cleft between programming and thought has emerged. "In programming what was formerly alphabetically written, thought will have detached itself from [now digital] language. And that is terrifying" (Flusser 2011a, p. 61). Because of this cleft between digital language and thought, thought also detaches itself from the means of programming behavior. The consequences are terrifying, according to Flusser. The goaloriented structure of historical thinking is replaced with a form of aimlessness and absence of historical consciousness. We have entered an a-historical present, aimless, and stupid in its disconnection from thinking - a caricature of thinking, in Flusser's words (Flusser 2011a, p. 157). As such, he foreshadows Stiegler's description of the present as a condition of profound disorientation in which both thought and individual and collective will are abolished. Whereas alphabetic writing is a gesture of historical consciousness, with the advent of digital writing, the belief that history matters is invalidated and we are liberated from the historical framework (Vlieghe 2014).

The so-called end of history and the current type of subjectivity are intimately related. The end of history implies "the equivalence between an unparalleled rate of change on all the levels of social life and an unparalleled standardization of everything - feelings along with consumer goods, language along with built space - that would seem incompatible with such mutability (...) What then dawns is the realization that no society has ever been as standardized as this one, and that the stream of human, social and historical temporality has never flowed quite so homogenously. (...) What we now begin to feel, therefore - and what begins to emerge as some deeper and more fundamental constitution of postmodernity itself, at least in its temporal dimension - is henceforth, where everything now submits to the perpetual change of fashion and media image, that nothing can change any longer" (Fischer 2009, p. 60). Technology is a main actor in the constitution of the rate of change and the standardization of everything. Citizens are encouraged to find solutions in products, not in politics. This also means that a collective subject, that is, a political subject that could take responsibility for the ecological catastrophe, is actively hindered to come into existence by capitalism. Fischer points to Capital as the deep-level cause and impersonal agent behind corporations and the behavior of individual agents, and responsible for the current catastrophe. In other words, according to Fischer (2009), consumer self-regulation and the market will not by themselves be able to avert ecological catastrophe. But the collective subject required for doing that is permanently delayed by the current use of technology (but see Bauwens and Lievens 2015, for another viewpoint).

Two years earlier, in Into the universe of technical images (2011b [1985]) Flusser discusses new social forms produced by technical revolutions. Discussing the circuitry of technical images (i.e. images produced by apparatuses and based on calculations), he contrasts the being scattered by images with true dialogue. Without entering the details 
of his account, it is clear that Flusser forwards the idea that the disappearance of collectivity and public space is related to the rise of the digital. Interestingly, he notices that people are complicit in the disappearance of public space where he remarks that people want to be scattered by images "so that they don't have to collect and assemble themselves, as they would if there were in fact a dialogue. They are happy not to have to do it anymore" (Flusser 2011b, p. 65). Whereas before, individuals related to public space in order to constitute ("assemble") themselves, now every dialogue is dangerous "because it could awaken the unhappy consciousness from its sleep" (ibid., p. 65). People are disinclined to collect themselves, and technical images have the intention to disperse people. "[P] eople want to disperse themselves to lose consciousness, to become happy" (ibid., p. 65). It is because unhappy consciousness is the only form of consciousness there is, that people shun dialogue and do not resist the disappearance of public space (cf. also the phenomenon of the filter bubble, Pariser 2012).

Thus, in Flusser's analysis, mass culture and the dispersal of society have resulted from a general desire to be happy. This happiness is a narcotized happiness, intellectually, morally and aesthetically of the level of the nursery. It is not the images themselves, but the current "feedback consensus" (ibid., p. 66) between technical images and people that prevents the awakening of fading consciousness. Flusser's notion of "feedback consensus" is interesting because it points to the implication of the subject in the diversity of feedback mechanisms and feedback loops in algorithmic governmentality. The implication of the subject in algorithmic governmentality (Rouvroy and Berns 2013) and hypernudging (Yeung 2017) has been given too little attention. Both in Flusser's and Stiegler's account, references to the desire of the subject occur in a context in which being manipulated figures centrally. How the desire of individuals to become happy paradoxically enslaves them to a regime that is destructive of the psychic and collective individual needs further examination. The idea of a form of complicity - the feedback consensus - in the destruction of historical consciousness, knowledge and public space is important.

Presently, digital writing and big data technologies are predominantly at the service of the economic imperatives of consumerism, destructing attention and historical, unhappy consciousness. Simultaneously, alphabetic writing is under pressure, leading to the destruction of knowledge - the characteristic of the Anthropocene according to Stiegler (Stiegler 2015a; Buseyne 2017). To consider the Anthropocene as an era in which people are generally narcotized and disoriented may enhance our understanding of why humans face the future and its ecological calamities (e.g. climate change) with apparent calm or non-action. But the picture is incomplete, because the motive and the desire for not awaking from the narcotized happiness of consumerism is not yet very clear. Both the knowledge of imminent ecological disaster, the general malaise consumers experience, and the increasing awareness that we are manipulated on a large-scale seem insufficient to turn the tide. It seems we face a strange riddle here, the solution of which must lie in the deeper structure of the form of subjectivity proper to the Anthropocene.

Let us recapitulate. People are enslaved to objects of commodified desire and this destroys the singularity of savoir-vivre. Desubjectivation is this destruction of singularity by the intentional promotion of herdish behavior by capitalist industries (cf. Sect. 2). One important factor in desubjectivation is the dynamic adaptation and unbridled market-driven personalization of the environment in order to control behavior of the individual (cf. supra). Stiegler $(2008,2015 b)$ analyzes this in terms of the loss of a sense of individual and collective existence. Identification with commodities or brands is short-lived and quickly leads to disillusion and disidentification, revealing emptiness and leading to the discovery that one 
is nothing, that is, one loses the sense of existence. Again, it is the structure of desire itself, and thus of subjectivity that is destroyed here in the hall of mirrors of commodities.

Desire, knowledge, and becoming a subject form a triangle that is under pressure in the Anthropocene. Different metaphors for preserving or restoring the triangle are circulating: the hacker (Wark), alphabetic writing (Flusser), long circuits of psychic and collective (co-)individuation, or an updated version of Foucault's care of the self (Stiegler). But all these philosophical therapies in some way presuppose one desire fundamental to or at least equipotent with all other desires: the desire to become a subject, this is, the desire to elevate oneself and not to become enslaved to commodification, leading to the destruction of the subject itself. In other words, the desire to become a subject is also the desire to live a life and to awaken unhappy consciousness from its narcotized slumber.

\section{Do We Want to Become Subjects? The Ambivalence of Desire}

To put the question straightforwardly: Do we, consumers, actually want to live a life, that is, do we want to become producer again of our own ways of existing? The implication of the subject in the technologically mediated dynamics of hypernudging and consumption may make the picture more complete but also more complex. The implication of the subject in its own disindividuation and in the experience of being nothing and being ahistorical requires our attention when portraying the contemporary individual. That individual is too often portrayed as in principle desiring to become a subject, but in practice hindered in that endeavor by relentless manipulation and commodification. In what follows, an outline is offered of the much more ambivalent attitude of humans towards their own subjectivity and thus towards their own desire of becoming a subject and living a life. This outline provides some necessary elements for understanding our remarkable inability to stop the consumerist destruction of the world.

In order to take the discussion a step further, we start from Robert Pfaller's notion of interpassivity (Pfaller 2014, 2017). Interpassivity is theorized as a strategy of escaping identification and subjectification (i.e. becoming a subject). When individuals are invited or summoned to become self-conscious subjects, they make use of interpassive means to flee into self-forgetfulness. According to Pfaller, interpassivity is a type of behavior and a type of ideology "that does not rest on becoming a subject" (Pfaller 2017, p. 8). Interestingly, the theory of interpassivity disentangles the at first sight bizarre phenomenon that people consume in order not to live their lives. In other words, people consume because they do not want to become subjects. Whereas it is correct to state that desubjectivation is a consequence of present-day consumption (cf. supra), Pfaller starts from the idea that this effect is sought after by the individual: consumption springs from the desire not to become a subject. On the one hand, Pfaller shows how capitalism promotes commodities with the promise of happiness, but on the other hand, he reveals a psychic structure that gains from consumerism and from not becoming a subject. Pfaller thus offers the elaboration of the much earlier suggestion by Vilém Flusser: people want to disperse themselves to lose consciousness, to become happy. Consumerist capitalism can only continue to exist because of a consensus in which the subject is implied.

Interpassive behavior exhibits the paradoxical structure of ambivalence: "In interpassive behaviour, people take up selective contact with a thing in order, in exchange, to entirely escape that very thing [...]" (Pfaller 2017, p. 8). Pfaller refers to Slavoj Žižek's work on cultural capitalism, that is, capitalism in which material objects primarily serve as props 
for an experience, for participation in a particular lifestyle or convictions. "Certain apples are not just fruit, but a promise of a health-conscious life or even an expression of ecological protest" (Pfaller 2017, p. 12). In addition to that, however, Pfaller is looking for the interpassive dimension of avoidance typical of consumerism. "[T] he majority of customers who buy four-wheel-drive off-road vehicles or so-called SUVs live in the city. They most likely know only from hearsay of rural life and of terrains that are difficult to drive on. The rough-and-ready car provides them a sense of "off-road' without ever having to go there" (Pfaller 2017, p. 13). What is typical of cultural capitalism, is that the "not doing' is the basis for the fulfilment of desire. In short, "a bit of life is purchased along with the product - and, furthermore, with the goal of not having to live it. The SUV takes care of it for us - it is rural leisure, in a similar fashion to an apple that is healthy in our place, or to trainers that are athletic on our behalf (after all, trainers are increasingly being worn by people who do ever less sport). In other words, cultural capitalist goods are dispatchers of vicarious life; they are interpassive media" (Pfaller 2017, p. 14).

The question is, of course, why interpassive behavior in the service of avoidance is so widespread, and thus why people do not want to have their lives. Why do people consume in order not to live their lives? One possible explanation is the ambivalent relation people have with the act they substitute (rural leisure being substituted by buying an SUV). The background idea here is that there is an ambivalent relation between people and their enjoyment (the enjoyment of the countryside). The wish or the desire involved is already linked with a discontent, and we live our life vicariously, such "that some pleasures do not have to be experienced any more" (Pfaller 2017, p. 43). Pfaller borrows this idea of ambivalence towards one's own pleasure from psychoanalytic theory, in which ambivalence is characterized as the simultaneous presence of opposing tendencies, such as love and hatred, towards the same thing, person or phenomenon.

What is important for our present purpose, however, is that interpassivity and the ambivalence at the heart of it may be the general structure of consumption (and not just of consuming ethical brands, as argued by Walz et al. 2014). Even though Pfaller considers the act of delegation, which is at the heart of interpassivity, as unconscious, the crucial insight is that consumers are not stupid, that means, they are not unaware of the empty core of their consumption. In other words, they know very well that consumption does not satisfy their desires and that all the promises of happiness by cultural capitalism are fake. ${ }^{2}$ The lack of satisfaction and its fake nature is precisely why we endlessly consume, not because we are deceived and manipulated, but because we know very well that is it just fake. For example, that I am attractive because I wear Chanel perfume is not something $I$ truly believe. Rather, when I 'believe' that, I rather imagine a consumer who believes that she is attractive by wearing Chanel perfume. I delegate the illusion of attractiveness (or health, fortune, success, intelligence, speed, power...) to an imagined naive consumer with whom I do not identify. The result is that my psychic interior remains empty from these naive illusions, and that I am not confronted with the wish or the desire itself - the wish to be desirable for others, the wish to overcome my own mortality - my pleasure lies in keeping all this - with the ambivalence inherent to it - at bay.

Distinctive of so-called illusions without owners is that the people who maintain these illusions, know that the illusion is silly or nonsensical. Knowing better does therefore not

\footnotetext{
${ }^{2}$ Fischer's term of 'depressive hedonia' (Fischer, 2009, p. 21) is also applicable to current forms of unbridled consumption. Whereas Fischer starts from symptoms of depression, Pfaller thinks in terms of an obsessive-compulsive psychic structure.
} 
dismiss this type of illusion. I know that drinking this brand of coffee will not bring closer family relationships. This lack of dismissal of the illusion by better knowledge renders the illusion elusive, i.e. difficult to recognize. Not only is it unclear who, or even if there is a bearer of the illusion; illusions without owners also seem evident only in those who know better. In other words, knowledge does not protect people from having this type of illusion. On the contrary, illusions without owners are more compelling than the illusions one owns (i.e. one's "truths"). The illusory idea of closer ties with my family by drinking a particular brand of coffee irresistibly drives me to consuming that brand of coffee. Its compulsive power is often the only characteristic that makes the presence of an illusion without owner manifest. This means that illusions without owners are not so much recognizable on the basis of their content. Because the knowledge that counters the illusion is often self-evident (e.g. I know my family won't get any closer on the basis of this type of coffee, even though advertisements display this image), the content of the illusion often seems unthinkable (I never think "If I buy this type of coffee, I will have a more intimate family life"). In short, we often are not aware that we are dealing with an illusion, even though we are acting on one.

Illusions with owners are much easier to recognize. The content of illusions with owners is manifest because it consists of anything we really believe (e.g. that gravity causes objects to fall, or, alternatively, that they gravitate to their natural place when falling). What is unknown (for the bearer of the illusion) is their truth-value, whereas illusions without owners are manifestly not true. What remains undetected, however, is that we compulsively act on illusions without owners. "The problem does not concern a mere lifting of the veil of a manifest illusion for the benefit of a truth that lies hidden behind it [this works for illusions with owners]. Instead, it concerns recognizing, at least, the additional presence of a veil where it seems as though nothing exists beyond self-evident, matter-of-fact knowledge of truth" (Pfaller 2014, p. 4). The problem is thus not that our picture of reality is false; the problem is rather that, in addition to the true (or possibly false) picture of reality, we also have another picture. This other picture of reality is the illusion without owner, the content of which remains unthought-of because of the veil concealing the illusion itself. According to Pfaller (2014), people can behave contrary to the knowledge they have, and in compliance with illusions of which they are not aware. The theoretical reconstruction of the illusion and its effectiveness (cf. the compulsive power of illusions without owners) would meet with "the ignorance and even amazed objection" of the people who maintain illusions without owners (ibid., p. 23).

\section{Illusions Without Owners and Compulsive Consumption in the Anthropocene}

We suggested that at the heart of consumption behavior a set of illusions is at work. This set consists of illusions without owners. No one truly believes the promises of happiness by consumerist capitalism. Consumers know better than that. Consumers are not stupid, they are not caught in the web of an illusion that could be replaced by a truth (e.g. the truth that consumption does not make one happy). No veil is to be lifted. Enlightenment 2.0. is not the solution: more knowledge cannot chase these illusions without owners because the necessary knowledge is already in place. The more troubling aspect is thus that better knowledge does not protect consumers from acting on these illusions without owners. The 'other picture' we have but do not believe ("Consumption means happiness! Let's consume 
more!") exists simultaneously with the 'true' picture of reality that compulsive consumption is disastrous both for our being as subject and for the Earth.

The better knowledge also prevents the person maintaining the illusion from coming into view as its owner. Illusions without owners and acting on these illusions are related on the basis of the structure of disavowal: despite of the better knowing, one acts on the basis of an illusion without owners. "I know quite well (that consumption does not make me happy) but still (consumption is the source of happiness)". As Pfaller (2014, p. 41) states, knowledge is not opposed to the illusion, but it is the condition for the devotion to the illusion!

The previous section mentioned that the content of the illusion often seems unthinkable. This implies that we often are not aware that we are dealing with an illusion. However, if the content of the illusion is held consciously, then it is assigned to others. This is also the reason why Pfaller's choice of words wavers between "illusions without owners" and "illusions of others". The illusion is assigned to others because in this way subjects try to escape from the content of the illusion. "They [people who maintain illusions without owners] take great pains to make clear that they are not the ones who correspond with what they feel is a disdainful image of a person who believes in the illusion" (ibid., p. 52). In that sense, believers (in illusions without owners) do not really believe in anything. Belief is assigned to a third person, an anonymous other held in check by the illusion.

In other words, illusions without owners (or the other to which the illusion is assigned) function as the condition of possibility for our consumerist behavior. The illusion is not a false belief held by someone, but a true condition of possibility without which we would only have one single picture of the world (the 'true' picture that our current way of consuming is disastrous). The 'other picture' (that consumption brings us happiness) is precisely not related to the empirical world, but relieves us from the task to act on the basis of our knowledge (the 'true' picture). Illusions without owners make up the collective transcendental conditions of subjectivity in the Anthropocene. Whereas modern thought was characterized by transcendental (i.e. non-empirical) conditions of possibility necessary for the possibility of objective knowledge (Immanuel Kant) or for the possibility of experience (Edmund Husserl), contemporary behavior seems to have illusions without owners as its transcendental conditions of possibility. Thus, our current transcendental conditions of possibility are themselves transcendental illusions, because they put a veil between our knowledge and our behavior, enabling current consumerist behavior. Therefore, it is not just the vectoralist class, not only big data technologies and their manipulative choice architects, not merely the deplorable loss of alphabetic writing and the rise of 'stupid' digital programming that enable and drive consumerist capitalism and destroy subjectivity. Subjectivity itself is structured by conditions of possibility that are exploited by contemporary technology, making up a vicious circle in which algorithmic governmentality based on big data technologies and the current type of ambivalent subjectivity are the main factors of unbridled consumption. Technology may have never before echoed this ambivalent core of subjectivity so strongly. Our relationship to technology has come to a point where we surface as a conundrum to ourselves: in its disconnection from thought we no longer understand our own irrational behavior and we are left with an endless, compulsive consumption. That matches the idea that the characteristic of the Anthropocene is above all the destruction of knowledge (Stiegler) or, in Flusser's terms, the disconnection between knowing and acting.

Even though both Stiegler and Flusser seem to situate the conditions of possibility in technology itself (the technologies of industrial democracies in Stiegler, digital writing and technical images in Flusser), both also recognize that the subject itself is implied in 
the disastrous consequences of the current technological era (the feedback consensus in Flusser, the death drive - which we did not discuss here - in Stiegler). ${ }^{3}$ The idea of illusions without owners adds the existence of an ambivalent subject to the discussion, this means, a subject disavowing an illusion it acts on compulsively. The issue of desire becomes central again where Pfaller situates this ambivalence in the economy of psychic energy or libido (desire). The ambivalence of the subject towards the illusion is, on the one hand, a recognition of the desirable side of the illusion (the love of consumption), but on the other hand the recognition that the content of the illusion is silly and stupid (the hatred towards consumption, present in better knowledge). What results is a conflict between dependency or love and disdain or hatred, and thus an ambivalent subject. Importantly, the conflict of positive (love) and negative (hatred) tendencies does not result in a cancellation of the powers involved, but the powers are added together (regardless of their focus or direction towards the positive or the negative). It is precisely this reinforcement that can explain the compulsive force of the illusions without owners. Whereas an unambiguous subject retains the necessary freedom to act or not to act on what she believes, the ambiguous subject is compulsively driven to act on the illusions assigned to the naive other: “(...) as long as positive tendencies alone compel an action, this action remains moderately necessary, an object of free choice. An action becomes compulsive, however, the moment when negative tendencies directed towards a certain goal and positive tendencies conducive to it unite because of an unconscious conflict (as the perfect compromise to please both sides)" (ibid., p. 103). "I know perfectly well ... but still ..." is therefore an adequate expression of this ambivalence. "With the help of ambivalence, it is possible to explain why certain people despise their own mindset [on the basis of better knowledge] and why, because of the fact that they despise this mindset, they are even more addicted to it than to any other mindset that they do not despise" (ibid., p. 106). The context of desire clarifies the status of "better knowledge' with regard to an illusion. 'It [the better knowledge] forms the affectless, intellectually cleansed track of the hatred [or the disdain] that contributed to the addition of the affects. 'Knowledge' is hatred. The contempt for the illusion that is caused by this 'knowledge' is added to the love granted by the illusion" (ibid., p. 104). As explained higher, the "addition of the affects" does not follow the rules of ordinary mathematics, where the negative (hatred) cancels out the positive (love). Typically for ambivalence, love and hatred reinforce each other, leaving the subject in the power of strong but ambivalent affects. Better knowledge is the intellectual and thus 'cleansed' trace of the affect of hatred. In that sense, better knowledge is a sign of contempt.

Pfaller's emphasis on the ambivalence of the subject thus offers a more nuanced view of the addicted, enslaved or compulsive nature of the behavior characteristic of consumerist societies. Without an ambivalent subject, technology could not fulfil its current role in

\footnotetext{
3 Other explanations also use terms from the field of psychology and psychopathology to explain our inability to act according to reality. Indeed, there is something odd about our knowledge of imminent or even current environmental catastrophe. According to Fischer (2009), its oddness lies in the fact that the environmental catastrophe is of the order of a traumatic void. That means that it is unrepresentable. In that sense, it is not part of reality (all realities being representable and imaginable). According to Fischer, "its [capitalism's] real implications for capitalism [are] too traumatic to be assimilated into the system" (Fischer, 2009, p. 18). In that sense, better knowledge once again does not prevent us from acting the way we do. On the contrary, every act of consumption tells us that the catastrophe is not yet there, that there is not yet a reason to truly change our acting. Consumption is one big collective ritual that shields us off from the confrontation with the traumatic void of ecological catastrophe or hyperobjects such as global warming (for the notion of 'hyperobjects', cf. Morton, 2013).
} 
the formation of consumerist societies. With the help of Pfaller we can explain why the belief in endless consumption is not destroyed by better knowledge. Illusions without owners function as condition of possibility for our acting against better knowledge, rendering the current form of subjectivity necessarily ambivalent. In turn, it is this ambivalence that makes up the core of the current addiction to consumption.

\section{The Unpleasure of Consumption and the Collapse of the Naive Other}

The 'other', the one who is held in check by the illusion also has a function, namely the function of naive observer and judge. As long as this naive observer has no better knowledge, behavior on the basis of the illusion is justified. The naive observer is not ambivalent: he represents our naive and positive attachment to consumption.

Pfaller's (2014) account of illusions without owners is not straightforwardly dismissive, however, because according to Pfaller, all cultural pleasure comes through illusions without owners and is dependent on the reigning social form of the illusion (ibid., p. 193). This means that the illusions of others are also the transcendental conditions of possibility for an alternative form of ideologically induced social cohesion. The illusion without owners, or the illusion of others (especially of the naive other), can be experienced in a pleasurable way. This happens when the pleasure that comes through disavowal (see "I know perfectly well ... but still ...") is not repressed. Repression, however, can cause the pleasure to be transformed into unpleasure. A major cause of the unpleasure in current consumerist capitalism is ecological awareness, repressing the pleasure people experience in consumption. Repression does not mean that the repressed pleasure disappears, to the contrary. The inability to experience pleasure in consumption, caused by ecological awareness and thus feelings of guilt, appears as desire for unpleasure. In short, it is a repression-based transformation of pleasure into unpleasure: “(...) a pleasure that is not permissible is able to break through in that it is lived out and experienced as unpleasure. Because people experience such emotions as unpleasure, they suffer; but because this unpleasure is based on pleasure, they can nonetheless not do without it" (ibid. p. 198). Ecological awareness thus paradoxically does not lead to a decrease in consumption. To the contrary, unpleasurable self-contempt because of the forbidden pleasure in consumption leads to the ambivalent pursuance of consumption.

In Capitalist Realism (2009), Mark Fischer also makes reference to Pfaller's work and his notion of interpassivity. ${ }^{4}$ According to Fischer (2009), capitalist ideology is not really held by anyone, "the operations of capital do not depend on any sort of subjectively assumed belief" (Fischer 2009, p. 12). A major reason is the invisibility of capitalist propaganda, which does not make any explicit case for something in a way similar to other big ideologies (e.g. nationalism, or earlier, communism and national socialism). No one really seems to endorse capitalist ideology in the sense that its ideology is transparent, apparently

\footnotetext{
${ }^{4}$ Fischer's use of Pfaller's work does not seem coherent. According to Fischer, it is not consumerist capitalism that is delegated or assigned to others, but anti-capitalism. For instance, in an interpassive way, we delegate anti-capitalism to a film like Wall-E. This delegation of anti-capitalist sentiments frees us from the burden to act in an anti-capitalist way ourselves, "allowing us to continue to consume with impunity" (Fischer 2009, p. 12). In this contribution, we do not claim that we consume with impunity (see the ambivalence and the unpleasure). And in contrast to Fischer, we claim that it is capitalist consumerism that is assigned to others, not anti-capitalist sentiments. Elsewhere, however, Fischer (rather implicitly) follows the analysis we offer here. It is this latter thread in his work that we highlight here.
} 
absent, or only held by others. No one makes a case for it in the way a case has to be made for non-dominant ideologies. Capitalist ideology is the illusion without owners. People no longer seem to believe in any ideological truth, not even the capitalist ideology. Ideology is no longer taken seriously. That also means that today's society seems post-ideological. The consequence is that everyone who takes up an openly ideological position (generally speaking, world-improvers) seems obsolete. Of course, we are far from being post-ideological because our behavior itself is shaped by the ideology of capitalism. As Slavoj Žižek points out: "Cynical distance is just one way (...) to blind ourselves to the structural power of ideological fantasy: even if we do not take things seriously, even if we keep an ironical distance, we are still doing them" (Žižek, cited in Fischer 2009, p. 12).

According to Fischer (2009), we all know that capitalist companies are corrupt and ruthless, a fact widely known and widely experienced. In the official version, however, many capitalist enterprises are presented as socially and environmentally responsible (cf. greenwashing). There is thus a division (or a condition of possibility) that allows social reality to function. No one really believes that capitalist enterprises are caring and concerned about the Earth and people's social conditions. That is to say: we believe it, but we also possess better knowledge that dismisses this belief. Capitalism as something ecologically caring is an illusion without owners. It is only people we despise who believe that capitalism is a good thing, this means, that it is not detrimental to the Earth. In the same way we do not believe in horoscopes (but nonetheless read them), we no longer believe that capitalism brings prosperity. But that does not hinder a deep-rooted ambivalence towards this belief, with all the consequences of compulsive consumption.

People resisting the idea that capitalism is good (so-called world-improvers) look for their enemies, this is, those owning the belief that capitalism is the right path to follow. They painstakingly make efforts to show that capitalism is bad, that it leads to social and environmental disaster. In other words, they try to demystify capitalism as the right ideology. According to Fischer, these "supposed gestures of demystification do not evince sophistication so much as a certain naivety" (Fischer 2009, p. 47), this is, a conviction that there are indeed others that still firmly believe in good old capitalism. What they do not see is that capitalist ideology is an illusion without owners. Therefore, the pressing issue is not so much to fight the true believers in capitalism, but to ask what would happen if the illusion without owners would collapse. After all, illusions without owners constitute the reigning social form and the condition of possibility for consumerist behavior by an ambivalent subject.

Thus, what would happen if the naive other loses its naivety? One could think that this is what we really need, because it would free us from the ambivalence that forms the motor of current consumer behavior, and because, consequently, it would free us from the addictive cycle or compulsory behavior.

But is the collapse of the naive other really a solution? Donald Trump, the president (2017-2021) of the USA, is an interesting case here, because he seems to personify the end of the belief in this naive other, looked upon with contempt. Importantly, it is not just traditional capitalism, but explicitly consumerist capitalism that is endorsed by Trump. Corey Robin describes how Trump is representative of a situation in which "the deck is stacked in favor of operators who can manipulate consumers, giving those buyers the illusion of finery rather than the reality of quality. 'The final key to the way I promote is bravado. I play to people's fantasies,' Trump writes. 'A little hyperbole never hurts. People want to believe that something is the biggest and the greatest and the most spectacular. I call it truthful hyperbole.' There is no stable or credible reality in Trump's economy. It's all spectacle, diversion, exaggeration, make-believe, daydream, pipe dream, imagination" 
(Robin 2017, n.p.). That Trump endorses this cynic view of current capitalism, shows how the end of capitalism is announced by capitalism itself. The breach in the illusion held by a naive other also means that the reigning social form of the illusion is nearing an end. Voting for Trump is therefore not stupid. It rather means that the current form of social cohesion, grounded in the belief in social progress on the basis of consumption, the current set of transcendental conditions of possibility that allows social reality to function, is on the verge of collapsing. In that sense, Stiegler is correct in stating that the irrationality of current hyper-industrial capitalism is no longer hidden. Thus, it may not be a rising ecological awareness that turns the tide, because this only adds to the repression of pleasure, but the sheer exhaustion of the libidinal system, turning into cynicism, that will bring about the end of consumerist capitalism.

\section{Conclusion}

The fact that we act ideologically (i.e. our behavior being shaped by capitalist ideology) is also why we are, in the facts, far from being post-historical. The philosophical idea of posthistory may be a symptom of or even a contribution to the reigning cynical position that is detrimental to any truly combative thinking or acting. The cynical distance is at the same time the abandonment of identifying us with what we do, with how we act. In Stiegler's terms, it is the abandonment of inventing our own ways of existing, and therefore the abandonment of a truly subjective position.

However, with the help of Pfaller, we have made clear that desubjectivation is not simply the result of consumption and manipulation, but that the subject is implied in its own destruction. This makes combative thinking or acting always partial and even divided. A 'solution' for the ambivalence at the heart of the subject in the Anthropocene is the collapse of the naive other. The collapse of the naive other can lead to the replacement of a covertly ambivalent subjective position by an overtly cynical one. Which other options the collapse of the naive other harbors is unclear. But it seems certain that the ambivalence of the subject, and the possible transition to cynicism are muddy waters for world-improvers. To clear up the transcendental conditions of possibility of the type of subjectivity characteristic of the Anthropocene may therefore make sense, or not.

Acknowledgements Research for this paper was funded by a research grant from KASK \& Conservatory, the school of arts of HOGENT and howest (BE).

Open Access This article is licensed under a Creative Commons Attribution 4.0 International License, which permits use, sharing, adaptation, distribution and reproduction in any medium or format, as long as you give appropriate credit to the original author(s) and the source, provide a link to the Creative Commons licence, and indicate if changes were made. The images or other third party material in this article are included in the article's Creative Commons licence, unless indicated otherwise in a credit line to the material. If material is not included in the article's Creative Commons licence and your intended use is not permitted by statutory regulation or exceeds the permitted use, you will need to obtain permission directly from the copyright holder. To view a copy of this licence, visit http://creativecommons.org/licenses/by/4.0/.

\section{References}

Bauwens, M., \& Lievens, J. (2015). De wereld redden. Met peer-to-peer naar een post-kapitalistische samenleving. Antwerpen: Hautekiet. 
Buseyne, B. A. (2017). Bernard Stieglers 'nouvelle critique' van de politieke economie. Vlaams Marxistisch Tijdschrift, 51(1), 69-84.

Fischer, M. (2009). Capitalist realism. Is there no alternative?. Alresford: John Hunt Publishing.

Flusser, V. (1977). Two approaches to the phenomenon: Television. In D. Davis \& A. Simmons (Eds.), The new television. A public/private art (pp. 234-247). Cambridge, MA: MIT Press. Online available as Toward a phenomenology of television (1977). (http://flusserbrasil.com/arte190.pdf).

Flusser, V. (2011a [first published in German in 1987]). Does writing have a future? (N. A. Roth \& M. Poster, Trans.). Electronic Mediations, vol. 33. Minneapolis/London: University of Minnesota Press.

Flusser, V. (2011b [first published in German in 1985]). Into the universe of technical images (N. A. Roth \& M. Poster, Trans.). Electronic Mediations, vol. 32. Minneapolis/London: University of Minnesota Press.

Morton, T. (2013). Hyperobjects. Philosophy and ecology after the end of the world. Minneapolis, MN: University of Minnesota Press.

Pariser, E. (2012). The filter bubble. What the internet is hiding from you. London: Penguin Books.

Pfaller, R. (2014 [2002]). On the pleasure principle in culture. Illusions without owners. London/New York: Verso.

Pfaller, R. (2017). Interpassivity. Edinburgh: Edinbrugh University Press.

Robin, C. (2017). Trump's fantasy capitalism. How the president undermines Republicans' traditional economic arguments. In The New Republic, November 13th 2017, online accessible at https://newrepubli c.com/article/145416/trumps-fantasy-capitalism-president-undermines-republicans-traditional-econo mic-arguments.

Rouvroy, A., \& Berns, Th. (2013). Algorithmic governmentality and prospects of emancipation. La Découverte, 1(177), 163-196.

Stiegler, B. (2008). Acting out. Stanford, CA: Stanford University Press.

Stiegler, B. (2011). The decadence of industrial democracies. Cambridge: Polity Press.

Stiegler, B. (2015a). Automatic society 1: The future of work - introduction (D. Ross, Trans.). La Deleuziana - Online Journal of Philosophy, 1, 121-140.

Stiegler, B. (2015b). "We moeten de quasi-oorzaak van het niets worden, van het nihil." Een interview met Bernard Stiegler.' Interview door J. Wambacq en B. Buseyne. De Uil van Minerva, 28(4), pp. 301-318.

Vlieghe, J. (2014). Education in an age of digital technologies. Flusser, Stiegler, and Agamben on the idea of the posthistorical. Philosophy \& Technology, 27(4), 519-537.

Walz, M., Hingston, S., \& Andéhn, M. (2014). The magic of ethical brands: Interpassivity and the thievish joy of delegated consumption. Ephemera, Theory \& Politics in Organization, 14(1), 57-80.

Wark, M. (2004). A hacker manifesto. Cambridge, Massachusetts, and London, England: Harvard University Press.

Williams, J. (2018). Stand out of our light. Freedom and resistance in the attention economy. Cambridge: Cambridge University Press.

Yeung, K. (2017). 'Hypernudge': Big Data as a mode of regulation by design. Information, Communication \& Society, 20(1), 118-136.

Publisher's Note Springer Nature remains neutral with regard to jurisdictional claims in published maps and institutional affiliations.

Helena De Preester studied philosophy at Ghent University (BE) and Université Libre de Bruxelles (BE) before completing her Ph.D. in Philosophy at Ghent University (2004). Her research topics focus on philosophy of technology (body, mind \& society), the human mind (self and subjectivity and the role of embodiment) and the relationships with art. She is currently professor of philosophy and researcher at the School of Arts, University of Applied Sciences and Arts Ghent and visiting research professor at the Department of Philosophy and Moral Sciences, Ghent University. She also holds a degree of Master of Science in Psychology (Clinical Psychology). Her most recent book publication (with Manos Tsakiris) is The Interoceptive Mind: From Homeostasis to Awareness (Oxford University Press, 2019). More information on helenadepreester.com. 